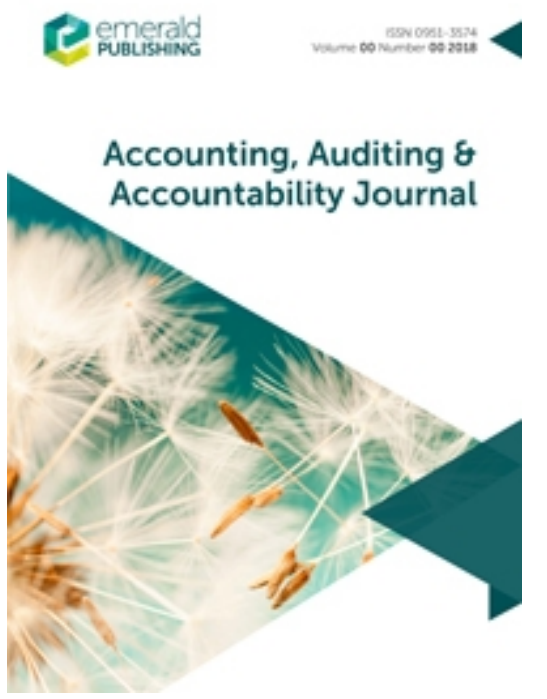

\title{
Accounting for (Public) Value(s): Reconsidering Publicness in Accounting Research and Practice
}

\begin{tabular}{|r|l|}
\hline Journal: & Accounting, Auditing \& Accountability Journal \\
\hline Manuscript ID & AAAJ-06-2021-5318 \\
\hline Manuscript Type: & Review Paper \\
\hline Keywords: & publicness, interdisciplinary, plural society, public value \\
\hline \multicolumn{2}{l}{} \\
\end{tabular}

SCHOLARONE $^{\text {TM }}$

Manuscripts 


\title{
Accounting for (Public) Value(s):
}

\section{Reconsidering Publicness in Accounting Research and Practice}

\begin{abstract}
Purpose - This paper highlights the importance of (public) value(s) and publicness in accounting and accountability research. It pinpoints a range of issues that scholars need to contemplate when reconsider publicness in accounting research and practice

Design/methodology/approach - The paper adopts an interdisciplinary literature review associated with a conceptual discussion of the actual and future challenges of public service accounting and accountability in considering public value(s).

Findings - The paper illustrates the centrality of (public) value(s) at the individual, organizational, and societal levels, in shaping and being shaped by calculative practices and show that looking at the interconnections between values and accounting is a fruitful research avenue. Moreover, it highlights the power of embracing interdisciplinary approaches to illuminate these interconnections and relate them to complex and current phenomena.

Originality/value - The paper's originality lays in the reconsideration of (public) value(s) for public service accounting scholar, providing a critical reflection and setting new research avenues.
\end{abstract}

\section{Introduction}

Public sector accounting scholarship has witnessed enormous developments over the last three decades (Broadbent and Guthrie, 1992, 2008; Lapsley, 1988; Steccolini, 2019). However, it has been criticised as being too insulated from other disciplines, with limited impact on public policy (Humphrey and Miller, 2012) also in need of stronger theorisation (Goddard, 2010; Jacobs, 2016; van Helden et al., 2008).

Public services are created in a complex environment, haunted by wicked problems (Jacobs and Cuganesan, 2014) and faced by shrinking resources, as well as the emergence of unexpected events and crises (Bracci et al., 2015), with the Covid-19 as the latest dramatic example. The attainment of public interest takes place in an abstract arena, rather than in the specific domain of public sector organisations, with the necessity to consider global and emerging issues such as climate change, sustainable economic development, biodiversity and ecological account (Bebbington and Unerman, 2018; Russell et al., 2017; Uddin and Tsamenyi, 2005; Weir, 2018). While the public sector can represent a context of research, publicness can represent an idea around which to develop research as the attainment of public goals and interests, rather than to the organisations and concrete spaces where the related activities take place. Interdisciplinary accounting scholars should explore how accounting and accountability can respond to the challenges posed by a shifting and increasingly intangible publicness (Cooper, 2005; Steccolini, 2019), calling for alternative accountability mechanism (e.g. integrated reporting, Villiers, Rinaldi, \& Unerman, 2014). Whereby accounting provides the processes and operational ways in which the public interest and public value are decided upon, planned, accounted for in an abstract public space (Miller \& Rose, 1990, 2008).

The concept of publicness emerged in public policy and administration literature following the seminal contribution of Bozeman (1987) arguing that all organisational forms are public to a certain extent. Since then, several contributions followed by defining the dimensions of publicness (Boyne, 2002), ethical issues (Berman et al., 1994), and decision processes (Nutt and Backoff, 1993). More 
generally, publicness refers more to the attainment of public value and interests, rather than to the organisations and concrete spaces where the related activities take place.

Focusing on publicness in public service accounting research is useful at least for three reasons (Steccolini, 2019). First, it may give meaning to "public sector and services", differentiating and specifying how "type(s)" of value(s) impacts on accounting and accountability. Second, relying on publicness as a multifaceted concept permits understandings the richness of extant fragmented contextual studies, by defining the boundaries and thus specifying under which conditions certain aspects are observed, and which are the features that impact on and are impacted upon by accounting. Third, it allows the reacting to previous calls for more engagement with policy and public administration literature, strengthening inter-disciplinarity and widening the impact of accounting studies. However, theoretical pluralism and paradigm diversity need not to leave behind the practical relevance and implications of the research (Van Der Meer-Kooistra and Vosselman, 2012).

In this paper, while introducing the content of the special issue, we aim at posing some new reflections on future developments of public service accounting and accountability research to bring publicness and public value(s) back in. In the next section, a discussion around the content of the papers in this special issue, and the implications for accounting research is presented. Section 3 presents a reflection, based on an interdisciplinary literature review, on the state of the art around reconsidering (public) value into accounting research. The last section sets some future avenues for the development of public service accounting and accountability research.

\section{Embracing a public perspective in Accounting: rediscovering the role of values and public values}

The contributions to this special issue highlight the centrality of (public) value(s) in defining and redefining the roles of accounting in the public space, though in a plurality of different meanings and with different implications.

The first paper (Vollmer, this issue) points to the need to rethink accounting in light of wider values than the traditional focus on finances, efficiency or effectiveness, opening up the scope for calculative practices to account for ecological needs and renewal, and for accounts to increasingly rely on multimodal and alternative formats, channels and "preparers" than traditional accounting and accountants. More specifically, Vollmer in his paper explores the role of accounting in ecological reconstitution and draws attention to the public value as a strategic focal point for developing it. The process of ecological reconstitution described by Latour in the "Politics of Nature" is traced towards a distinct set of accounting practices, designated as full-tax accounting. The author discusses how full-tax accounting may contribute to the creation of a planetary public towards the inclusion of nonhuman planetarians. As media facilitating immersion and togetherness, these accounts, which are offered by outsiders (for instance by academics and political activists, journalists, by other people) of the outside (nature), circulate as complex combinations of signs and media, as messages that are "multimodal. It establishes matters of care and haunts constitutional processes with the specter of exclusion so as to avoid compromising the ecological change and renewal and get back to the divide between nature and society. Starting with full-tax accountants, the author envisage the emergency of planetary publicvalue accountants, from eco-critics to the preparers of biodiversity reports and to activists on social media, which act as curators of matters of care and aim to overcome the traditional deficits of the "accounting eye" (Hopwood, 1992: 132-34). Broad alliances among planetary accountants are suggested as needed to extend the terms of ecological reconstitution, to gain and preserve attunement to matters of care and defend these attunements.

The need to rethink the scope of accounting to embrace wider perspectives and values is similarly reflected in the Quayle et al paper (this issue), where the authors challenge accounting's limited focus on accounting fraud and financial misstatement and develop a public interest theoretical framework. In so doing, the authors depict whistleblowing as a public value activity that moves organizational 
wrongdoing into the public sphere where it is subject to democratic debate and dialogue required to reconcile the public's interests with public values. As the content of whistleblowing evolve to embrace new concerns related to the public interest or public value outside the view of traditional accounting frameworks, accounting should find a new position with respect to the public interest and expand its boundaries to incorporate the various social, political, moral, and environmental dimension of public value.

The plurality of values in our societies, economies, organizations, and their potential for conflict and competition, will often place governments in the position to find compromises among them.

A paradigmatic illustration of the potential tensions emerging from different values and interests is offered by Giner and Mora (this issue). By recognizing that public interest is controversial, differs among stakeholders and is contingent on circumstances, the paper by Giner and Mora looks at how public interest is operationalized and pursued in an extreme circumstance where a country faces a dilemma between calling for a bailout for the whole country, or asking for a specific type of financial aid, which would allow the recapitalization of banks. In particular, by integrating the agency framework with a legal and political framework based on the balancing approach and Raz's (1994) order reasoning, the paper analyzes the interference of the Spanish government in the accounting of financial entities by issuing accounting standards in contradiction with IFRS, interfering in the accounting practice of highly politically connected banks, as well as the silence of enforcers and other stakeholders. The break of accounting rules was justified in light of the political interpretation of public interest - avoiding the bailout of the whole country and the negative consequences for the economic well-being - as opposed to the operationalization of public interest of financial reporting of the global standard setter. The authors show that this justification was considerate as legitimate due to the critical situation faced by the Country and proportionate and did not raised opposition by enforcers as, consistently with the balancing approach, a breach of rules is perceived less relevant after a high-level decision. However, the authors warn that breaking the rule, despite its apparently and immediate positive consequences, may have other unintended and long-term consequences, and significant costs that were not measured or not attracted high attention, or even were hindered, when the decision of non-compliance with IFRS was taken.

The three last papers in the special issue offer a further view on the relationship between accounting and values, showing the concrete ways in which accounting can translate them into practice, and how accounting can contribute to, while being shaped by, a change in values.

The paper by Höglund et al. (this issue) uses Moore's strategic triangle as an analytical framework to study strategic management and management control practices in relation to public value. Drawing on the Swedish case of the Region Stockholm (RS) and its Culture unit, the paper enhances understanding of the conceptualization and operationalization of public value in practice by advancing three propositions on the reasons that may explain why the alignment of the three nodes of the strategic triangle (i.e. authorizing environment, public value creation and operational capacity) may be lost, thus, compromising the ability to successful strategizing for long-term value creation. The propositions suggested that this strategic alignment is vulnerable to: 1) management control practices that have a strong focus on performance measurement; 2) standardized management control practices that may limit managerial autonomy; 3) politically driven management control practices in that it may result in short-term goals and an increased focus on measurable output, rather than supporting visionary goals and long-term public value. The above propositions suggest that accounting should pay attention to consider the complexity of the strategic work of public value creation (Crosby et al., 2014). Complexity not only related to the presence of different stakeholders, but also to the interplay of different levels of national, regional and local actors to support the longterm value creation.

Following a normative approach to publicness and combining two relation approaches, governmentality and actor-network theory, the paper by Closs-Davies, Bartels and Merkl-Davies (this 
issue) investigates how accounting technologies are implicated in the transformation of public values. In particular, by looking at UK tax authority, Her Majesty's Revenue and Customs (HMRC) and the daily practices of its workers, the authors show that the traditional public administration values were transformed into neoliberal values through a gradual process that made the new neoliberal values so deeply engrained and normalized that most workers were unaware of their impact on working practices. This process has been effectively described in the paper by using the analogy of the "frog in the pan", which is based on the reaction of a frog placed in a pan of water. If the water is boiling, the will immediately jump out, whereas if the water slowly warms up, the frog does not notice and is boiled alive. The authors have identified three emergent properties of accounting that facilitated the gradual change of power relationships and public values within HMRC: 1) disconnecting workers and claimants spatially and socially through frequent reallocation and re-categorization into isolated locales; 2) losing touch with the embodied and holistic nature of tax administration as the increased use of ICT standardized the re-presentation of citizens in abstract and coded forms; and 3) yielding to performance management systems, which subjectified workers by constantly surveying, assessing and sanctioning them, fostering values such as efficiency and competition while disempowering relational values such as respect, trust, responsiveness and care.

Along similar lines, the paper by Brackley et al. (this issue) analyses how the contested value(s) of healthy life and wellbeing is reconstructed in two Local Authorities in England in the years after a major restructure of local government and the National Health Service promoted by the reforms of the Health and Social Care Act 2012 and in a context in which agencies have lost a large part of their budgets through successive rounds of austerity cuts. Drawing on Science and Technology Studies scholars and Karen Barad's (2007) agential realism, the paper sheds light on how ethics and politics are embedded in, produced and reproduced through calculative and discursive devices that are contested, amended, and mobilized in everyday interventions across organizational boundaries. In doing so, the paper also explores how the "public value" is interactively (re)articulated and (re)defined through 'intelligent accountabilities' and discusses the challenges related to the creation of collaborative ethical accounts in times of austerity measures.

Overall, the papers of this special issue all illustrate the relevance of (public) value(s) at the individual, organizational, and societal levels, in shaping and being shaped by calculative practices and show that looking at the interconnections between values and accounting is a fruitful research avenue. In more detail, they are particularly powerful in pointing to the need to better understand the implications of pluralism, as well as of their dynamics over time for accounting and accounting scholarship. Besides, they help to understand how accounting can give voice to different perspectives, also through an increase in its scope, and provide the very processes through which they find voice and representation, as well as the mediating arena where conflicts and compromises, as well as changes in values, are promoted and brought forward. In particular, Vollmer (this issue) as well as Quayle et al. (this issue) point to the plurality and width of values which needs to be incorporated and brought forward by accounting and accountants, therefore not only challenging the scope and modes of accounting but also the prepares of accounts (insiders versus outsiders) and roles of accountants. The papers in this issue also show that prioritizing and compromising across/among values is and will be the challenge for governments and public service organizations, with accounting playing a central role in operationalizing and translating values in practice. While Höglund et al. (this issue) point to the role of accounting practices in undermining strategies aimed at achieving public value, ClossDavies (this issue) and Brackley et al. (this issue) show the importance of (public) values, and how they affect accounting, and in turn accounting plays a fundamental role in shaping or changing them, even diminishing public values.

At the same time, the papers in the special issue also point to the power of embracing interdisciplinary approaches to illuminate complex and current phenomena such as environment protection and conservation, corruption and ethics, financial crisis, health and well-being. They have addressed their 
research questions by engaging with theories and concepts borrowed from other fields, such as Foucault, Callon, Latour, Barad and Raz. This appears to encourage us to reflect on whether the interdisciplinary accounting community may explore even stronger ways of pushing interdisciplinarity further.

\section{Reconsidering the roles of (public) values in accounting research}

The wave of managerial reforms in the public sector and the ensuing time of austerity (Bracci et al., 2015) have often conveyed a very limited view of accounting by emphasizing its predominant economizing role in our societies (Miller and Power, 2013). Accounting is seen as one of the ways to translate the ideals of managerialism and marketization, or austerity into practical tools. Accruals based reporting and accounting, new forms of performance measurement and management accounting allowed governments, policymakers, and managers to give visibility and primacy to issues of efficiency, effectiveness, orientation to outputs, emphasizing economic and financial rationality and de-emphasizing democratic, political, citizens' perspectives on balancing budgets and financial measures of performance. Yet, the papers in this special issue all point to the need to recognize that the potential scope of accounting is much wider than (as much as relevant they may be) "holding managers" accountable for outputs, infusing the public sector with a result orientation, or better measuring costs of services, and government debts.

As argued out elsewhere, "[a]ccounting scholars, thus, need to look at how accounting can respond to the challenges posed by a shifting and increasingly "diffused" publicness. As public interest and public value are decided upon, planned and accounted for out of a specific tangible space, and in an abstract public space, accounting can still provide the processes and operational ways in which this happens, and through which general values and ideas are translated into day-by-day decisions and actions [...] (Steccolini, 2019).

The above opens up the reflection on the value(s) and the types of publicness with the implications for accounting scholarship. This involves taking advantage of the stock of knowledge in other fields and re-defining the boundaries between accounting and other disciplines, and, thus, responding to previous calls for more engagement with policy and public administration literature (Jacobs, 2016).

As such, understanding accounting in a public space requires making the underlying values and ideas explicit, never taking them for granted. Even if accounting has been described as a forceful economizing driver (Miller and Power, 2013), the contributions in this special issue provide further evidence, adding to the current debate on the scope of accounting, and thus suggesting that there is a need to look at the interrelationships between (types of) values and calculative practices with renewed interest and perhaps from novel theoretical and methodological perspectives.

While a preoccupation with the interrelationship between values and accounting is not new in our discipline, how it has been observed and studied has witnessed interesting evolutions. Institutionalist (Modell, 2021; Safari et al., 2020; Scapens, 2006) and other sociological approaches (Armstrong, 2015; Ezzamel, 1994; Humphrey et al., 1993; Skærbæk and Tryggestad, 2010) have widely documented how new accounting systems have often been adopted in public sector accounting studies, and accounting studies more generally, as conceptual lenses to understand the role of accounting in changing organizational culture from bureaucratic, Weberian values to managerial ones (Chow and Bracci, 2020; Hyndman and Liguori, 2016; Liguori and Steccolini, 2012). Along similar lines, the increasing predominance of "NPM" values and their unexpected and unwanted effects have been the subject of enduring critique in interdisciplinary accounting research (Hyndman and Lapsley, 2016; Jacobs, 2016).

A further development in institutionalism has witnessed the application of "multiple logics" perspectives in better understanding processes of change. Ezzamel et al. (2012) showed how competing logics in the accounting field impact on budgeting practices, explaining the variations as 
well as the budgetary outcomes. The existence of multiple, and often competing, logics can lead to the development of forms of accounting, organizational and identity hybrids (Kastberg and Siverbo, 2016; Kurunmäki and Miller, 2006; Vakkuri et al., 2021). Addressing hybridity in public services is multidimensional as it involves forms of hybrids in the institutional dynamics, structures, agency and practices, and roles and identity (Denis et al., 2015). The traditional institutional boundaries are therefore put under question in a process of hybridization of knowledge, identity, rules, technologies and structures. We have examples of studies addressing how accounting changes/reform can bring forwards new logics affecting the functioning of the organizations and/or the identity of actors. Kurunmäki (2004) showed how health-care professionals were hybridized by accounting reforms, while Carlsson-Wall et al. (2016) showed similar pattern in social workers, and Becker et al. (2014) in public sector accountants.

Critical accounting scholars have also suggested the need to "take pluralism" more seriously (Brown, 2009; Brown et al., 2015; Dillard and Vinnari 2018. Brown et al. (2015) argue that in pluralistic society, with many concurrent and competing values, accounting, accountants and accountability are required to draw on conceptual and practice-based resources from and across different disciplines. There is wide-ranging recognition of the need for "new accountings" that foster democracy and facilitate more participatory forms of social organization. This is particularly evident in the sustainable development and social and environmental accounting literatures, with calls for more dialogic forms of accounting. (Brown, 2009: 313, Dillard and Vinnari 2018)

More recently, accounting scholarship has received a new infusion of stimuli coming from the sociology of worth and evaluation studies (e.g. Lamont, 2012). Sociology of worth and evaluation has become increasingly influential in accounting studies (Chenhall et al., 2013; Mennicken and Sjögren, 2015; Samiolo, 2012) to observe how accounting supported the diffusion of an increasing demand by government and the general public for the quantification of social phenomena. According to Lamont (2012), neoliberalism pushed governments towards greater use of quantitative measures of performance and benchmarking, with (re)structuring effects on institutions and individuals. Lamont (2012) highlighted the valuation of a certain entity is intrinsically related to the values and criteria of the quantification process. As such, he calls for a better understanding of valuation and evaluative processes and practices (Lamont, 2012: 203). Samiolo (2012) showed how quantification and economic calculation go beyond the objectivity of the numbers, as it is debated, stabilized or disrupted depending on the appeals to realism or accuracy. The rational process of commensuration was dissolved by the search of coexistence of polycentric power centers. Examining valuations and how things are made valuable is of interest for accounting studies, as accounting is able to render particular quantification robust, pervasive and flexible (Mennicken and Sjögren, 2015). Modell (2021) argues that the sociology of valuation is relevant in contemporary public services. The latter are continuously pressured to quantify, compare, benchmark but without a real critique on the process of quantification and commensuration. Modell (2021) suggests to study accounting quantification drawing on the sociology of valuation but paying attention both to the process, the actors and the institutional effects as accounting practices unfold through time. Among other aspects, the sociology of worth/evaluation, while pointing often to the roles played by accounting in making object commensurable (Espeland and Sauder, 2007; Espeland and Stevens, 2008), also highlights the compresence of a plurality of "worlds of worth" (Boltanski and Thevenot, 2007), which impose plural expectations and criteria for evaluation on individuals, organizations, and governments.

It is worth noticing that parallel developments in studying public value and values have been brought forward by public administration scholars. In response to the neo-liberal paradigm which has dominated the 'new public management' movement, a public value literature has flourished over the last years (Alford and O'Flynn, 2009; Bozeman, 2007; Bryson et al., 2014; Jørgensen and Bozeman, 2002; Jørgensen and Rutgers, 2015; Moore, 1995; Nabatchi, 2010; Prebble, 2015; Rutgers, 2015; Talbot, 2009; Van der Wal et al., 2015). This literature has evolved around two main strands of research. The first stream is populated by studies inspired by the work of Mark Moore. Following 
Moore's approach $(1995,2013,2014)$, these studies focus on organizational level and on managerial issues related to the creation of public value, defined as what would benefit the public and that the public would value as well. The second stream, started by Bozeman (2007), focuses on the policy and societal level and refers to public values, which are "those providing normative consensus about the rights, benefits, and prerogatives to which citizens should (and should not) be entitled; the obligations of citizens to society, the state, and one another; and the principles on which governments and policies should be based. (Bozeman 2007, 13)"

Studies on public values are concerned about identifying and enacting those values considered as public values (Fukumoto and Bozeman, 2019). Interestingly, pluralism is a distinctive trait of the public value literature and is reflected in all the attempts that have been conducted to identify and classify public values (de Graaf et al., 2016; Jørgensen and Bozeman, 2002; Rutgers, 2015). While, this element of pluralism is pervasive to public administration (Nabatchi, 2012), it was obfuscated by the NPM with its emphasis on efficiency as a central value. However, recently it is attracting again attention (Huijbregts et al., 2021; Nabatchi, 2012; Van Der Wal et al., 2015). In particular, several scholars have shown that public value conflicts may emerge as the realization of certain public values contrast the pursuit of other people's values. For example, de Graaf and Paanakker (2015) argue that a common conflict in public governance is between lawfulness and transparency. De Graaf, Huberts, and Smulders (2016), through a case study of a municipality, show that the most common value was between transparency and effectiveness. de Graaf and Meijer (2019) point that the use of social media produces new value conflicts in public governance, specifically, conflicts between efficiency and participation and between transparency and lawfulness. To address public values conflict and ambiguity several mechanisms and strategies are applied, with some of them operating at the organizational level (de Graaf and Meijer, 2019; Thacher and Rein, 2004) and others entailing the direct and active involvement of citizens (Nabatchi 2012). However, as pointed in a recent work by Huijbregts et al (2021), there is not an universal solution when managers and police makers have to identify and decide upon competing values, being the design and methods used for the assessment of public values dependent on the temporal and spatial perspective, influenced by rationality and routinization that characterize the policy issue to be tackled. Moreover, value conflicts may be difficult to measure and compare, especially when there are different and not commensurable values at stake. The developments in public administration literature therefore represent useful stimuli for accounting scholars, (inviting us) to explore the roles of accounting in identifying, shaping and changing public value(s). It has been argued elsewhere (Bracci et al., 2019) that public accounting research needs to start considering public value more seriously and moving "away from the disciplinary 'comfort zone' by exploring the margins" and not the technical core of accounting and/or following a monolithic economics-based paradigm.

The above considerations show that there is the tendency to increasingly recognize the potential of accounting to represent the heterogeneous and plural values expressed by societies, organizations and individuals, support decisions among these values, and to contribute to transformation of values over time. Exploring this potential further is of particular relevance in the public space, where even the very concept of public performance is subject to interpretation, deliberation, discussion, becoming ambiguous, politically charged, and being multi-faceted (Cuganesan et al., 2014; Rautiainen, 2010), and the use of information will also reflect underlying conflicts or differences in perspectives (Giacomini et al., 2016,). As pointed out by Vosselman (2014), "accounting is not an essence in itself, but can only exist in processes of knowing in networks, and is in politics."(p.199).

\section{Conclusion (reflection and new ways forward)}

In the pre-covid world we had already entered a post-NPM reflection, which questioned the narrow scope of accounting, aimed at translating specific economic-focused, neoliberal-type, E-E-E-type, values into practical tools (and decisions). Covid-19 however has increasingly exposed the 
heterogeneity of our societies, and the plurality and trade-offs between values (health vs economy, egalitarianism vs elitism, novax vs pro-vax, prioritization of individual vs community, full transparency vs privacy, individual freedom vs collective safety, transparency vs effectiveness). This is even made more evident by the expansion of our digital lives through social media, which are allowing an unprecedented expansion in the forms and modes of information and communication, and of expression of diverging interests and values. The pandemic posed policy makers and public managers in front of tradeoffs among competing values: health versus economic and individual freedom, collective interest versus individual privacy (Yang, 2020). This values balance, apart from the emergency periods, is always present in public services policy and delivery. The debate around the achievement of the United Nations (UN) Sustainable Developments Goals already questioned how to sustain well-being within the capacity of the planet and with a developing economic system that is also equitable and sustainable (Bebbington et al., 2019). To achieve such global challenges, it means creating public value, involving public and private organizations to put SDGs as their common interest, a public interest of sort (Abhayawansa et al., 2021).

This suggests that the interconnections between values and accounting are likely to continue to remain high in the interdisciplinary accounting agenda. As pointed out above, the papers in this special issue appear to show that pushing the boundaries of interdisciplinarity, and seeking even stronger form of pluralism in our studies, combining a plurality of perspectives, may strengthen the exploratory and explanatory power of our studies, as well as their policy and practical relevance (Steccolini, 2019). The renewed interest in this area suggests however, that additional perspectives may enrich the literature, by recognizing the richness of pluralism at three levels: pluralism in our societies; in our theories; and in our methods. Bebbington et al. (2019) is an example of cross-disciplinary contribution connecting accounting and accountability with the hard science debate on the Anthropocene. The authors show how this may lead to bring back and contribute with known concepts, to some extent marginalized, such as that of stewardship in the discussion over accountability. Bringing the public back-in may allow to go beyond decades of NPM debates, and mainstream consideration of the primacy of efficiency, rationality and principal agents relations (Steccolini, 2019). This however require us to accept that the «values» measured and expressed by accounting may be wider in scope, plural, and discursively constructed (Brown, 2009; Moore, 2014). At the same time, accounting and accountability research and practice can, and to some extent need to, evolve into something new. As an example, Douglas and Overmans (2020) propose an advancement of the way public budgeting is conceptualized and managed, by advancing the concept of public value budgeting, beyond the traditional financial controls, and the Weberians vs managerial debate. De facto, accounting is fluid and mobile in nature and developed through time as an assemblage of calculative practices and rationales (Miller, 1998).

The papers in this special issue provide an impetus and encouragement for (accounting) scholars to bring forward our reflections on accounting for (public) value(s) and to devote more attention to the pluralism of societal as well as public and administrative values and their possible implications for accounting, accountants, reporting and financial management.

Along these lines, there are a number of possible open questions and issues to be addressed. We particularly encourage scholars to explore how accounting can contribute to a better understanding of public values(s), beyond a merely economic perspective and to investigate the role of accounting in identifying, shaping and translating different perspectives, values and interests (especially those of vulnerable, less powerful and marginalized stakeholders). As such, there appears to be a need to consider more seriously pluralism of values and how they affect accounting and vice-versa. A future fruitful research avenue may also refer to how the combination of different interests, actors, values, processes affect the current idea of performance «valued» in a certain reality (Modell, 2015); also investigating how values are operationalized, following which bases and standards and in which processes are those measures used. A further possible research area which requires attention refers to 
how (processes and forms) and from what sources accounts incorporating different dimensions of public value emerge and how do they interact/affect managers, citizens, politicians and other stakeholders. In this line, it will be relevant to investigate how public value and performance are continuously re-assessed, re-discussed, and made the subject of measurement and reporting. In reporting standards, there is still little consideration for democratic accountability besides "economic" accountability, with no preoccupation around social equity and the environment. Public sector accounting research and accountants are asked sustain public managers and politicians in developing democratic dialogues beyond financial and non-financial reporting.

We look forward to further studies that address the above issues and contribute to the debate around the interconnections between accounting and (public) value(s) in a rapidly changing globalized and networked world. The challenge will be to avoid narrowness in conducting research, while attempting to innovate methods, informing theories and values so to contribute to the broader social goods and global well-being. 
References

Alford J and O'Flynn J (2009) Making sense of public value: concepts, critiques and emergent meanings. International Journal of Public Administration 32(3-4): 171-191.

Armstrong P (2015) The discourse of Michel Foucault: A sociological encounter. Critical Perspectives on Accounting 27: 29-42..

Barad K (2007) Meeting the Universe Halfway: Quantum Physics and the Entanglement of Matter and Meaning. Durham: Duke University Press.

Bebbington J and Unerman J (2018) Achieving the United Nations Sustainable Development Goals. Accounting, Auditing \& Accountability Journal 31(1): 2-24. Available from: http://www.emeraldinsight.com/doi/10.1108/AAAJ-05-2017-2929 (accessed 17 May 2018).

Becker SD, Jagalla T and Skærbæk P (2014) The translation of accrual accounting and budgeting and the reconfiguration of public sector accountants' identities. Critical Perspectives on Accounting, Elsevier Ltd 25(4-5): 324-338. Available from: http://dx.doi.org/10.1016/j.cpa.2013.05.004.

Berman E, West J and Cava A (1994) Ethics Management in Municipal Governments and Large Firms: Exploring Similarities and Differences. Administration \& Society, SAGE Publications Inc. 26(2): 185-203. Available from: http://aas.sagepub.com/cgi/doi/10.1177/009539979402600204 (accessed 11 January 2017).

Boltanski L and Thevenot L (2007) De la justification: les économiesde la grandeur. Revue de Métaphysique et de Morale.

Boyne GA (2002) Public and Private Management: What's the Difference? Journal of Management Studies, Blackwell Publishers Ltd. 39(1): 97-122. Available from: http://doi.wiley.com/10.1111/1467-6486.00284 (accessed 11 January 2017).

Bozeman B (1987) All organizations are public. Washington, DC: Jossey-Bass.

Bozeman B (2007) Public values and public interest: Counterbalancing economic individualism. Washington, DC: Georgetown University Press.

Bracci E, Humphrey C, Moll J, et al. (2015) Public sector accounting, accountability and austerity: more than balancing the books? Accounting, Auditing \& Accountability Journal 28(6): 878908.

Bracci E, Papi L, Bigoni M, et al. (2019) Public value and public sector accounting research: a structured literature review. Journal of Public Budgeting, Accounting \& Financial Management 31(1): 103-136. Available from: https://www.emeraldinsight.com/doi/10.1108/JPBAFM-07-2018-0077.

Broadbent J and Guthrie J (1992) Changes in the Public Sector: A Review of Recent "Alternative" Accounting Research. Accounting, Auditing \& Accountability Journal 5(2): 09513579210011835.

Broadbent J and Guthrie J (2008) Public sector to public services: 20 years of "contextual" accounting research. Accounting, Auditing \& Accountability Journal 21(2): 129-169. Available from: http://www.emeraldinsight.com/doi/abs/10.1108/09513570810854383.

Brown J (2009) Democracy, sustainability and dialogic accounting technologies: Taking pluralism seriously. Critical Perspectives on Accounting 20(3): 313-342.

Brown J, Dillard J and Hopper T (2015) Accounting, accountants and accountability regimes in pluralistic societies. Judy Brown, Professor Jesse Dillard P (ed.), Accounting, Auditing \& Accountability Journal 28(5): 626-650. Available from: https://www.emerald.com/insight/content/doi/10.1108/AAAJ-03-2015-1996/full/html.

Bryson JM, Crosby BC and Bloomberg L (2014) Public Value Governance: Moving Beyond Traditional Public Administration and the New Public Management. Public Administration Review 74(4): 445-456. Available from: http://doi.wiley.com/10.1111/puar.12238.

Carlsson-Wall M, Kraus K, Lund M, et al. (2016) 'Accounting Talk' Through Metaphorical Representations: Change Agents and Organisational Change in Home-Based Elderly Care. European Accounting Review 25(2): 215-243. Available from: 
http://www.tandfonline.com/doi/full/10.1080/09638180.2014.992921.

Chenhall RH, Hall M and Smith D (2013) Performance measurement, modes of evaluation and the development of compromising accounts. Accounting, Organizations and Society, Elsevier Ltd 38(4): 268-287. Available from: http://dx.doi.org/10.1016/j.aos.2013.06.002.

Chow D and Bracci E (2020) Neoliberalism, accounting, and the transformation of subjectivities in social work: A study on the implementation of personal budgets. Financial Accountability \& Management 36(2): 151-170. Available from:

https://onlinelibrary.wiley.com/doi/abs/10.1111/faam.12231.

Cooper C (2005) Accounting for the public interest: public ineffectuals or public intellectuals? Accounting, Auditing \& Accountability Journal 18(5): 592-607. Available from: http://www.emeraldinsight.com/10.1108/09513570510620466 (accessed 3 September 2013).

Crosby B, Bloomberg L and Bryson J (2014) Public Value Governance: Moving Beyond Traditional Public Administration and the New Public Management. Public Administration Review 74(4): 445-456.

Cuganesan S, Guthrie J and Vranic V (2014) The riskiness of public sector performance measurement: a review and research agenda. Financial Accountability \& Management 30(3): 279-302. Available from: http://doi.wiley.com/10.1111/faam.12037.

de Graaf G and Meijer A (2019) Social Media and Value Conflicts: An Explorative Study of the Dutch Police. Public Administration Review 79(1): 82-92.

de Graaf G and Paanakker H (2015) Good Governance: Performance Values and Procedural Values in Conflict. American Review of Public Administration 45(6): 635-652.

de Graaf G, Huberts L and Smulders R (2016) Coping With Public Value Conflicts. Administration and Society 48(9): 1101-1127.

Denis J-L, Ferlie E and Van Gestel N (2015) Understanding Hybridity in Public Organizations. Public Administration 93(2): 273-289. Available from: http://doi.wiley.com/10.1111/padm.12175.

Douglas S and Overmans T (2020) Public value budgeting: propositions for the future of budgeting. Journal of Public Budgeting, Accounting and Financial Management 32(4): 623-637.

Espeland WN and Sauder M (2007) Rankings and reactivity: How public measures recreate social worlds. American Journal of Sociology 113(1): 1-40.

Espeland WN and Stevens ML (2008) A Sociology of Quantification. European Journal of Sociology 49(3): 401-436. Available from: http://www.journals.cambridge.org/abstract_S0003975609000150 (accessed 10 August 2017).

Ezzamel M (1994) Organizational Change and Accounting: Understanding the Budgeting System in its Organizational Context. Organization Studies 15(2): 213-240. Available from: http://oss.sagepub.com/content/15/2/213.short (accessed 16 April 2014).

Ezzamel M, Robson K and Stapleton P (2012) The logics of budgeting: Theorization and practice variation in the educational field. Accounting, Organizations and Society, Elsevier Ltd 37(5): 281-303.

Fukumoto E and Bozeman B (2019) Public Values Theory: What Is Missing? American Review of Public Administration 49(6): 635-648.

Giner B and Mora A (2020) Political interference in private entities' financial reporting and the public interest: evidence from the Spanish financial crisis. Accounting, Auditing and Accountability Journal.

Goddard A (2010) Contemporary public sector accounting research - An international comparison of journal papers. The British Accounting Review 42(2): 75-87. Available from: http://www.sciencedirect.com/science/article/pii/S0890838910000235 (accessed 29 October 2014).

Höglund L, Mårtensson M and Thomson K (2021) Strategic management, management control practices and public value creation: the strategic triangle in the Swedish public sector. Accounting, Auditing \& Accountability Journal ahead-of-p(ahead-of-print). Available from: 
https://www.emerald.com/insight/content/doi/10.1108/AAAJ-11-2019-4284/full/html.

Hopwood A (1992) Accounting calculation and the shifting sphere of the economic. European Accounting Review 1(1): 125-143.

Huijbregts R, George B and Bekkers V (2021) Public values assessment as a practice: integration of evidence and research agenda. Public Management Review, Routledge 00(00): 1-20. Available from: https://doi.org/10.1080/14719037.2020.1867227.

Humphrey C and Miller P (2012) Rethinking impact and redefining responsibility. Accounting, Auditing \& Accountability Journal 25(2): 295-327. Available from: http://www.emeraldinsight.com/doi/abs/10.1108/09513571211198773 (accessed 6 May 2015).

Humphrey C, Miller P and Scapens RW (1993) Accountability and accountable management in the UK public sector. Accounting Auditing \& Accountability Journal 6(3): 7-29.

Hyndman N and Lapsley I (2016) New Public Management: The Story Continues. Financial Accountability \& Management 32(4): 385-408. Available from: http://doi.wiley.com/10.1111/faam.12100.

Hyndman N and Liguori M (2016) Public Sector Reforms: Changing Contours on an NPM Landscape Public Sector Reforms. Financial Accountability \& Management 32(1): 5-32.

Jacobs K (2016) Theorising Interdisciplinary Public Sector Accounting Research. Financial Accountability \& Management 32(4): 469-488. Available from: http://doi.wiley.com/10.1111/faam.12093.

Jacobs K and Cuganesan S (2014) Interdisciplinary accounting research in public sector: dissolving boundaries to tackle wicked problems. Accounting, Auditing \& Accountability Journal 27(8): $1250-1256$.

Jan van Helden G, Johnsen $\AA$ and Vakkuri J (2008) Distinctive research patterns on public sector performance measurement of public administration and accounting disciplines. Public Management Review 10: 641-651.

Jørgensen TB and Bozeman B (2002) Public Values Lost? Comparing cases on contracting out from Denmark and the United States. Public Management Review 4(1): 63-81. Available from: http://www.tandfonline.com/doi/abs/10.1080/14616670110101681 (accessed 13 September 2013).

Jørgensen TB and Rutgers MR (2015) Public Values: Core or Confusion? Introduction to the Centrality and Puzzlement of Public Values Research. American Review of Public Administration 45(1): 3-12.

Kastberg G and Siverbo S (2016) The role of management accounting and control in making professional organizations horizontal. Accounting, Auditing \& Accountability Journal 29(3): 428-451. Available from: https://doi.org/10.1108/AAAJ-03-2014-1632 (accessed 7 June 2017).

Kurunmäki L (2004) A hybrid profession - The acquisition of management accounting expertise by medical professionals. Accounting, Organizations and Society 29(3-4): 327-347.

Kurunmäki L and Miller P (2006) Modernising government: the calculating self, hybridisation and performance measurement. Financial Accountability \& Management 22(1): 87-106. Available from: http://eprints.1se.ac.uk/20461/.

Lamont M (2012) Toward a comparative sociology of valuation and evaluation. Annual Review of Sociology 38(April): 201-221.

Lapsley I (1988) Research in Public Sector Accounting: An Appraisal. Accounting, Auditing \& Accountability Journal 1(1): 21-33. Available from: https://doi.org/10.1108/EUM0000000004618 (accessed 17 May 2018).

Liguori M and Steccolini I (2012) Accounting change: explaining the outcomes, interpreting the process. Accounting, Auditing \& Accountability Journal 25(1): 27-70. Available from: http://www.emeraldinsight.com/10.1108/09513571211191743 (accessed 8 August 2013).

Mennicken A and Sjögren E (2015) Valuation and Calculation at the Margins. Valuation Studies 3(1): $1-7$. 
Miller P (1998) The margins of accounting. European Accounting Review 7(4): 605-621.

Miller P and Power M (2013) Accounting, Organizing, and Economizing. The Academy of Management Annals 7(1): 557-605.

Miller P and Rose N (1990) Governing economic life. Economy and Society 19(1): 1-31.

Miller P and Rose NS (2008) Governing the present : administering economic, social and personal life. London: Polity.

Modell S (2021) New developments in institutional research on performance measurement and management in the public sector. Journal of Public Budgeting, Accounting \& Financial Management ahead-of-p(ahead-of-print).

Moore MH (1995) Creating public value: strategic management in government. Cambridge MA: Harvard University Press.

Nabatchi T (2010) Putting the 'Public'Back in Public Values Research: Designing Public Participation to Identify and Respond to Public Values. Kupa.Ku.Edu 72(315): 699-708. Available from: http://www.kupa.ku.edu/classes/documents/NabatchiPublicValuesandParticipation.pdf.

Nabatchi T (2012) Putting the 'Public' Back in Public Values Research: Designing Participation to Identify and Respond to Values. Public Administration Review 72(5): 699-708.

Nutt PC and Backoff RW (1993) Organizational Publicness And Its Implications For Strategic Management. Journal of Public Administration Research and Theory, Oxford University Press 3(2): 209-231.

Prebble M (2015) Public Value and Limits to Collaboration. International Journal of Public Administration, Routledge 38(7): 473-485. Available from: http://dx.doi.org/10.1080/01900692.2014.949742.

Rautiainen A (2010) Contending legitimations. Accounting, Auditing \& Accountability Journal 23(3): 373-391.

Raz J (1994) Ethics in the Public Domain: Essays in the Morality ofLaw and Politics. Oxford, UK.: Clarendon Press.

Russell S, Milne MJ and Dey C (2017) Accounts of nature and the nature of accounts. Accounting, Auditing \& Accountability Journal 30(7): 1426-1458. Available from: http://www.emeraldinsight.com/doi/10.1108/AAAJ-07-2017-3010 (accessed 17 May 2018).

Rutgers MR (2015) As Good as It Gets? On the Meaning of Public Value in the Study of Policy and Management. American Review of Public Administration 45(1): 29-45.

Safari M, Bicudo de Castro V and Steccolini I (2020) The interplay between home and host logics of accountability in multinational corporations (MNCs): the case of the Fundão dam disaster. Accounting, Auditing \& Accountability Journal ahead-of-p(ahead-of-print). Available from: https://www.emerald.com/insight/content/doi/10.1108/AAAJ-03-2019-3912/full/html.

Samiolo R (2012) Commensuration and styles of reasoning: Venice, cost-benefit, and the defence of place. Accounting, Organizations and Society, Elsevier Ltd 37(6): 382-402. Available from: http://dx.doi.org/10.1016/j.aos.2012.04.001.

Scapens RW (2006) Understanding management accounting practices: A personal journey. The British Accounting Review 38(1): 1-30.

Skærbæk P and Tryggestad K (2010) The role of accounting devices in performing corporate strategy. Accounting, Organizations and Society 35(1): 108-124.

Steccolini I (2019) Accounting and the post-new public management. Accounting, Auditing \& Accountability Journal 32(1): 255-279. Available from: https://www.emeraldinsight.com/doi/10.1108/AAAJ-03-2018-3423.

Talbot C (2009) Public Value-The Next "Big Thing” in Public Management? International Journal of Public Administration 32(3-4): 167-170. Available from: http://www.tandfonline.com/doi/abs/10.1080/01900690902772059.

Thacher D and Rein M (2004) Managing value conflict in public policy. Governance 17(4): 457486. 
Uddin S and Tsamenyi M (2005) Public sector reforms and the public interest. Accounting, Auditing \& Accountability Journal 18(5): 648-674. Available from: http://www.scopus.com/inward/record.url?eid=2-s2.0-25444436435\&partnerID=tZOtx3y1.

Vakkuri J, Johanson J-E, Feng NC, et al. (2021) Governance and accountability in hybrid organizations - past, present and future. Journal of Public Budgeting, Accounting \& Financial Management ahead-of-p(ahead-of-print). Available from: https://www.emerald.com/insight/content/doi/10.1108/JPBAFM-02-2021-0033/full/html.

Van Der Meer-Kooistra J and Vosselman E (2012) Research paradigms, theoretical pluralism and the practical relevance of management accounting knowledge. Qualitative Research in Accounting and Management 9(3): 245-264.

Van der Wal Z, Nabatchi T and De Graaf G (2015) From Galaxies to Universe: A CrossDisciplinary Review and Analysis of Public Values Publications From 1969 to 2012. American Review of Public Administration 45(1): 13-28.

Van Der Wal Z, Nabatchi T and De Graaf G (2015) From Galaxies to Universe: A CrossDisciplinary Review and Analysis of Public Values Publications From 1969 to 2012. American Review of Public Administration 45(1): 13-28.

Villiers C de, Rinaldi L and Unerman J (2014) Integrated reporting: Insights, gaps and an agenda for future research. Accounting Auditing and Accountability Journal 27(7): 1042-1067.

Vollmer H (2020) Public value and the planet: accounting in ecological reconstitution. Accounting, Auditing \& Accountability Journal ahead-of-p(ahead-of-print). Available from: https://www.emerald.com/insight/content/doi/10.1108/AAAJ-11-2019-4283/full/html.

Weir K (2018) The purposes, promises and compromises of extinction accounting in the UK public sector. Accounting, Auditing \& Accountability Journal 31(3): 875-899. Available from: https://www.emeraldinsight.com/doi/pdfplus/10.1108/AAAJ-03-2016-2494 (accessed 17 May 2018). 